Vol. 17 (2008): 165-176.

\title{
Impact of spring warming on sowing times of cereal, potato and sugar beet in Finland
}

\author{
Timo Kaukoranta and Kaija Hakala \\ MTT Agrifood Research Finland, Plant Production Research, FI-31600 Jokioinen, Finland, \\ e-mail: timo.kaukoranta@mtt.fi
}

\begin{abstract}
Historical data were used to determine if the warm springs experienced in recent decades have influenced time of sowing of spring cereals (barley, wheat and oats), potato and sugar beet in Finland. The start of the thermal growing season was used to represent all climatic factors affecting sowing time. Regional anomalies in sowing and start of growing season were computed for the years 1965-2007. The start of the growing season was 2-2.8 days earlier per decade, with a steeper increase since 1980 . Sugar beet sowing advanced 2.5 (since 19805.2 ) and potato planting 3.4 (since 19804.5 ) days per decade, more than expected solely due to earlier starts to the growing season. Sowing of spring cereals advanced $0.6,0.7$ and 1.7 days per decade in the east, north and west respectively (since $19801.0,1.9$ and 3.1), with statistically significant trend ( $p<$ 0.01 ) in the west. Earlier sowings can be largely explained by warmer springs, but the trend was not as steep as that for the growing season. This has however not led to increased temperatures during early vegetative phases and thus faster development and increased drought or pest risk, which would have reduced the positive effects of earlier sowing on yield potential. Earlier sowing detected in the west can be explained by changes in spring temperatures, but may also result from economic and technological development. Farmers seem to have adequately adjusted their field activities to the changes in spring temperatures.
\end{abstract}

Key-words: climate change, adaptation, cereals, potato, sugar beet, sowing time

\section{Introduction}

The global mean temperature has increased by 0.6 $\pm 0.2^{\circ} \mathrm{C}$ over the past century (1901-2000) (IPCC 2001), a trend that has accelerated to $0.74 \pm 0.18^{\circ} \mathrm{C}$ during 1906-2005 (IPCC 2007). In Finland, mean annual temperatures have increased similarly $\left(0.7^{\circ} \mathrm{C}\right)$ with the largest increase in the spring (March to May, MAM) (Tuomenvirta 2004). Since 1960, both spring and winter (December-February) temperatures rose by about $1{ }^{\circ} \mathrm{C}$; winter temperatures rose slightly more, but inter-annual variation was much wider than that for spring temperatures. The 


\section{AGRICULTURAL AND FOOD SCIENCE}

Kaukoranta, T. and Hakala, K. Time of sowing affected by spring warming

enhanced greenhouse effect, warming of the earth's surface due to increasing atmospheric greenhouse gas concentrations, is expected to raise winter temperatures by 1.2 to $5^{\circ} \mathrm{C}$ by $2010-2039$ relative to the average for 1961-1990, spring temperatures by 1.1 to $4.2^{\circ} \mathrm{C}$ and summer temperatures (June-August) by 0.6 to $1.6^{\circ} \mathrm{C}$ (Jylhä et al. 2004).

Carter (1998) established that, in accordance with the overall increase in mean temperatures, the growing season, defined as the period when daily mean temperatures are continuously above $5^{\circ} \mathrm{C}$, lengthened in Finland and Scandinavia by one to three weeks during the 100 year period from 1895 to 1995. In Finland, the lengthening has been more significant at the start of the growing season than at the end. For Scandinavia the reverse is true. He also provided estimates of the future growing season using the central temperature scenario developed by the Finnish Research Programme on Climate Change (SILMU, Carter 1996). These estimates projected a $2.4^{\circ} \mathrm{C}$ warmer spring (MAM) by 2050 relative to 1961-1990, which translated into lengthening of the growing season by about 25 days (Carter 1998).

There is convincing evidence for earlier onset of growth of perennial crops and of plants in natural ecosystems as a result of warmer springs during the past 40 years (e.g. Schwartz and Reiter 2000, Menzel 2003, Delbart 2005, Menzel et al. 2006a, Estrella et al. 2007) and evidence for the faster development of winter annuals (Hu et al. 2005, Estrella et al. 2007). Carter (1998) inferred that if the start of growing season is earlier in the spring, then some evidence of earlier sowing of spring cereals might be expected in records from long-term variety trials or other sources reflecting standard farming practices. There are, however, few published results on observed effects on farming activities in the spring. Chmielewski et al. (2004) reported that sowing of maize (Zea mays L.) and sugar beet (Beta vulgaris L. var. altissima) advanced by 6-8 days from 1960 to 2000 in Germany. Estrella et al. (2007) summarized data and computed trends in phenological events and sowing and harvesting in Germany. Most of their data on annual crops are for autumn-sown crops, sown earlier in the autumn. Regarding spring-sown crops they reported that sowing of oats (Avena sativa L.) has not advanced, but linear advancement of maize sowing has been 2.3 days and that of sugar beet 1.9 days per decade. Menzel et al. (2006b) noted that in Germany farmers' activities in the spring lagged behind the recorded warming.

Spring-sown crops are mostly grown in the semicontinental climate of northern Europe. The length of the period from sowing in the spring to harvesting in the autumn is mainly restricted by melting soil frost in the spring and subsequent warming and drying of soil, and by low temperatures in the autumn. Cereals and some sugar beet are grown on heavy soils (clay, silt) that hold sufficient moisture for tilling and seed germination only during a very short period, lasting one to two weeks. After the soil has dried adequately to allow seedbed preparation, farmers aim to sow cereals and sugar beet as early as possible to utilize soil moisture from snow melt and to reduce the risk of late harvesting in autumn. However, farmers have been cautious not to sow too early, in order to avoid damage caused by frosts to sensitive crops and to cereals at the flowering stage.

There are long-term technological and economic changes that are expected to have affected the time of sowing. Of these the most obvious since the 1960s are steadily increasing field areas per farm combined with reduced area under grass crops, improved efficiency of machinery and increased pressure on farmers to maximize field productivity. Fields themselves changed, as open ditches were largely replaced by covered drainage in the 1960s and 1970s.

The aim of this study was to establish whether farmers in Finland have responded to spring and winter warming and have adjusted their field work accordingly. The study focused on spring-sown cereals as a group (barley (Hordeum vulgare L.), wheat (Triticum aestivum L.) and oats), potato (Solanum tuberosum L.) and sugar beet.

\section{Material and methods}

The physiological optimum of timing of sowing a field in the spring is determined by a chain of events starting in the preceding autumn and ending at the day of sowing. To predict accurately the sowing 
Vol. 17 (2008): 165-176.

time, soil temperature and humidity balance need to be computed using a physical model forced by local historical weather data. A less demanding approach, more in tune with the available data and the aims of this study, is to use statistical techniques to relate observed climate and sowing times.

The most common starting and ending points of sowing of spring cereals, sugar beet and potato have been recorded by advisors from the ProAgria Rural Advisory Centres (later in the text, Advisory Centre) since 1965 and entered into a database by the Ministry of Agriculture and Forestry. The dates are not based on formal farm level reporting or sampling, but on observations made by the advisors. The data contain dates for the start and end of sowing of each plant group studied here, in every year and in each Advisory Centre. Each Advisory Centre covers 70 to 290 thousand hectares of cultivated area. The Advisory Centres are identified by numbers in Fig. 1, with their corresponding names given in Table 1.

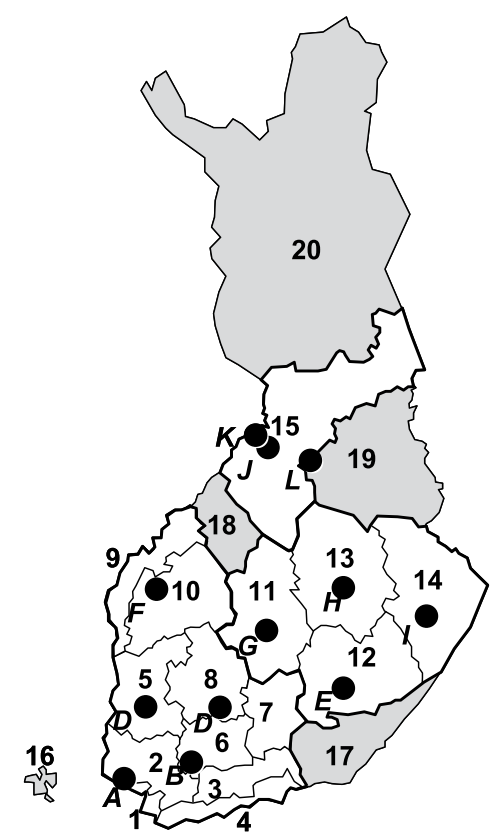

Fig. 1. ProAgria Rural Advisory Centres in 1965-2007. Advisory Centres are given in Table 1 by number. Points indicate location of weather stations, which are marked by a letter and named in Table 2. Data from shaded Advisory Centres were excluded as incomplete.
Advisory Centres where continuous time series were not available, Åland, Kaakkois-Suomi and Keski-Pohjanmaa, were excluded. Kainuu and Lappi were also excluded because of their low propor-

Table 1. ProAgria Rural Advisory Centres in 1965-2007 and their total cultivated area and fallow area (CA) (1000 ha) in 2006. Source: Ministry of Agriculture and Forestry Statistical Office (TIKE).

\begin{tabular}{|c|c|c|}
\hline Region & Advisory Centre & $\mathrm{CA}$ \\
\hline \multicolumn{3}{|l|}{ West } \\
\hline 1. & Finska Hullshållss. (-1997) & \\
\hline 2. & Varsinais-Suomi & 291 \\
\hline 3. & Uusimaa & 184 \\
\hline 4. & Nylands Svenska (-1997) & \\
\hline 5. & Satakunta & 143 \\
\hline 6. & Häme & 188 \\
\hline 7. & Itä-Häme (-1997) & \\
\hline 8. & Pirkanmaa & 162 \\
\hline 9. & Österbottens Svenska (-1997) & \\
\hline 10. & Etelä-Pohjanmaa & 243 \\
\hline \multicolumn{3}{|l|}{ East } \\
\hline 11. & Keski-Suomi & 93 \\
\hline 12. & Etelä-Savo & 71 \\
\hline 13. & Pohjois-Savo & 142 \\
\hline 14. & Pohjois-Karjala & 87 \\
\hline \multicolumn{3}{|l|}{ North } \\
\hline 15. & Pohjois-Pohjanmaa & 210 \\
\hline \multicolumn{3}{|c|}{ Not included in data } \\
\hline 16. & Åland (1999-) & 14 \\
\hline 17. & Kaakkois-Suomi & 140 \\
\hline 18. & Keski-Pohjanmaa & 93 \\
\hline 19. & Kainuu & 30 \\
\hline 20. & Lappi & 43 \\
\hline
\end{tabular}

Table 2. Sites and official codes of weather stations of the Finnish Meteorological Institute.

\begin{tabular}{lll}
\hline & Site & Code \\
\hline A & Mietoinen & 1003 \\
B & Jokioinen & 1201 \\
C & Kokemäki & 1104 \\
D & Pälkäne & 1306 \\
E & Mikkeli & 2602 \\
F & Ylistaro & 3101 \\
G & Jyväskylä & 2401 \\
H & Maaninka & 3603 \\
I & Joensuu & 3801 \\
J & Ruukki & 5402 \\
K & Oulunsalo & 5401 \\
L & Vaala & 5502 \\
\hline
\end{tabular}


Kaukoranta, T. and Hakala, K. Time of sowing affected by spring warming

tion of cultivated area. In 1998 eight Centres were merged: coastal Nylands Svenska with Uusimaa, coastal Finska Hushållssälskap with VarsinaisSuomi, coastal Österbotten with Etelä-Pohjanmaa and Itä-Häme with Häme. For the merged Advisory Centres before 1998, the values of the coastal Advisory Centres were selected, where sowing tended to occur slightly earlier than inland. For Itä-Häme and Häme, values from Häme were used. For studying potato, only data from Häme, Satakunta, EteläPohjanmaa/Österbotten were included because production is concentrated mainly in these Advisory Centres. For studying sugar beet, data from Advisory Centres with the largest production were used: Uusimaa/Nylands Svenska, Varsinais-Suomi/ Finska Hushållssälskap, Häme and Satakunta.

As the observations might have been affected by personnel changes over the decades, merging of Advisory Centres and because of different rates of decline of farms growing grass crops in the Advisory Centres, analyzing changes separately in every Advisory Centre was considered potentially misleading. While trying to avoid overuse of data, but attempting to retain possible regional differences, three regions were formed: west, east, and north (Table 1). The west is dominated by arable farming; it has a more maritime climate, and larger farms and fields than the east. In the east the climate is characterized by colder winters, thicker snow cover and often less soil frost than in the west, and rapid warming in the spring. The north contains only one Advisory Centre, Pohjois-Pohjanmaa, where most arable land is on the western coast. Only the start of sowing (S) was analyzed for two reasons. Firstly, the end of sowing followed mostly S; and secondly, the end of sowing is likely to have been affected more than $\mathrm{S}$ by the change of economic and technological factors. Improving machinery efficiency has reduced the time needed for tilling and sowing unit areas of arable land, but simultaneously farms have expanded and area under grass crops has markedly diminished.

Annual anomalies for $\mathrm{S}$ of each crop in the years 1965-2007 relative to their means in 1971-2000 were computed for each Advisory Centre. These values were averaged over the regions west, east and north to produce regional anomalies for $\mathrm{S}$.
Least squares linear trends of S over 1965-2007 were computed for each region and their significance was tested with the non-parametric MannKendall test, which is considered more statistically robust than parametric tests for detecting a trend, using the program MULTIMK/ PARTMK (Grimvall, A. \& Libiseller, C., Linköping University, Swedish University of Agricultural Sciences).

Temperature data were obtained from 11 weather stations of the Finnish Meteorological Institute (FMI), which operated over the entire monitoring period. The weather stations are marked on the map in Fig. 1, identified by a letter, with names and FMI weather station codes given in Table 2. Weather stations in Jyväskylä, Joensuu and Oulunsalo are located at airports, but are surrounded by rural areas. All other stations are in rural areas.

The start of the thermal growing season is the date when daily mean temperatures permanently exceed $5^{\circ} \mathrm{C}$ in the spring. Original daily data and the definition of the start of growing season used by FMI (no snow, daily mean temperatures in five consecutive days above $5^{\circ} \mathrm{C}$, sum of positive deviations from the mean temperature larger than sum of negative deviations) was first tried for establishing the regional anomalies for the start of growing season relative to the mean for 1971-2000 (G). As $\mathrm{G}$ determined this way predicted S poorly, the temperature data were smoothed. Two types of smoothing were computed: (a) daily moving average of 31 days, (b) daily data interpolated from monthly mean temperatures. Lengthening the period of averaging to at least 31 days improved explanatory power of $\mathrm{G}$ on S. For both types (a, b) of data, G was computed for the regions west, east and north. Least squares linear trends of G over 1965-2007 were computed for each region and their significance was tested with the Mann-Kendall test.

Regression models with autoregressive errors predicting $\mathrm{S}$ from $\mathrm{G}$ and year were constructed. A model structure that gave best fit in terms of diagnostics (autocorrelation, significance of parameter estimates, model variance) was selected for each region and crop type. The model parameters were estimated using SAS PROC AUTOREG (SAS Institute Inc., Cary, NC, USA). To confirm that annual variation of $\mathrm{S}$ actually responded to the 
Vol. 17 (2008): 165-176.

variation of $\mathrm{G}$ and their trends were not merely parallel, time series were detrended by first differencing (differenced $\mathrm{S}=\mathrm{S}_{\mathrm{t}}-\mathrm{S}_{\mathrm{t}-1}$, differenced $\mathrm{G}$ $=\mathrm{G}_{\mathrm{t}}-\mathrm{G}_{\mathrm{t}-1}$ ) and regressions were computed using the detrended data.

To establish if the mean temperature during the period of early vegetative phase of cereals has changed, annual anomalies of mean temperature for the three-week period, beginning 10 days after the start of sowing, were computed for each region and crop from observed daily mean temperatures. Trends were tested with SAS PROC AUTOREG.

\section{Results}

In the east and the north the linear regression trends for $\mathrm{G}$ in 1965-2007 towards an earlier start were 2.1 days per decade, and in the west 2.8 days per decade, if computed from data smoothed by central moving average of 31 days. If $\mathrm{G}$ was computed from monthly mean temperatures, the trends towards an earlier start were 2.0, 2.3 and 2.6 days per decade for east, north and west, respectively. All trends were significant $(p<0.01)$. Annual values of $\mathrm{G}$ in the three regions computed from moving average data are shown in Figs. 2-6.
The earliest S were in the early 1990s and after 2000, but early S also occurred in 1965, 1975, 1983 and 1984 (Figs. 2-6). For all crops, in all the regions and years, early sowings occurred when the start of the growing season was early. The linear trends during 1965-2007 for the S of spring cereals show advances in sowing date in all regions (Figs. $2-4)$ : in the east 0.6 days per decade, in the north 0.7 days, and in the west 1.7 days. Only in the west was the trend significant $(p<0.01)$ according to the Mann-Kendall test (Table 3). The trends of S of potato and sugar beet, estimated only for the west, show significant advances in sowing date during 1965-2007 (Table 3). The S of potato advanced 3.4 days per decade (Fig. 5) and the $\mathrm{S}$ of sugar beet 2.5 days (Fig. 6).

$\mathrm{S}$ of spring cereals was strongly and significantly correlated with $\mathrm{G}$ in all regions (Table 3) and could be best explained by regressing $S$ of spring cereals on $\mathrm{G}$ only (Table 4). In the west, the correlation of $S$ of spring cereals with $G$ was higher if $\mathrm{G}$ was computed from (a) monthly mean temperatures, instead of (b) data smoothed by moving average (Table 3 ). In the regression analysis $\mathrm{S}$ of spring cereals could be best explained with $G$ without a year effect (Table 4). The advances of S of potato and sugar beet were as high as or higher than the advances in G. G explained a large part of variation of $\mathrm{S}$ of potato and sugar beet, but for these

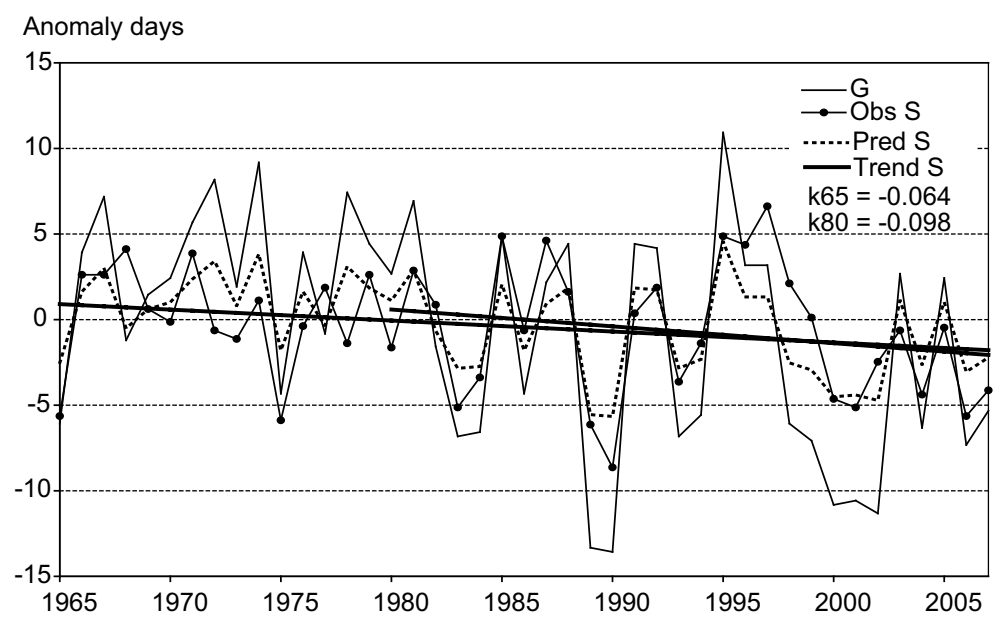

Fig. 2. Spring cereals in region east of Finland. Anomaly of growing season start relative to mean of 1971-2000 (G) and anomaly of start of sowing: observed (Obs S), predicted (Pred $S=0.417 \times \mathrm{G})$, and linear trend during 1965-2007 and 1980-2007 (Trend S). Slope of trend since $1965(\mathrm{k} 65)$, since 1980 (k80). 
Kaukoranta, T. and Hakala, K. Time of sowing affected by spring warming

Fig. 3. Spring cereals in region north in Finland. Anomaly of growing season start relative to mean of 1971-2000 (G) and anomaly of start of sowing: observed (Obs $\mathrm{S})$, predicted (Pred $\mathrm{S}=0.381 \times \mathrm{G})$, and linear trend during 1965-2007 and 1980-2007 (Trend S). Slope of trend since 1965 (k65), and since $1980(\mathrm{k} 80)$.

Fig. 4. Spring cereals in region west in Finland. Anomaly of growing season start relative to mean of 1971-2000 (G) and anomaly of start of sowing: observed (Obs $\mathrm{S}$ ), predicted (Pred $S=0.483 \times G)$, and linear trend during 1965-2007 and 1980-2007 (Trend S). Slope of trend since 1965 (k65), since 1980 (k80).

Fig. 5. Potato in region west of Finland. Anomaly of growing season start relative to mean of 1971-2000 (G) and anomaly of start of planting: observed (Obs S), predicted (Pred $\mathrm{S}=441+0.425 \times \mathrm{G}-0.223 *$ Year), and linear trend during 1965-2007 and 1980-2007 (Trend S). Slope of trend since 1965 (k65), since 1980 (k80).
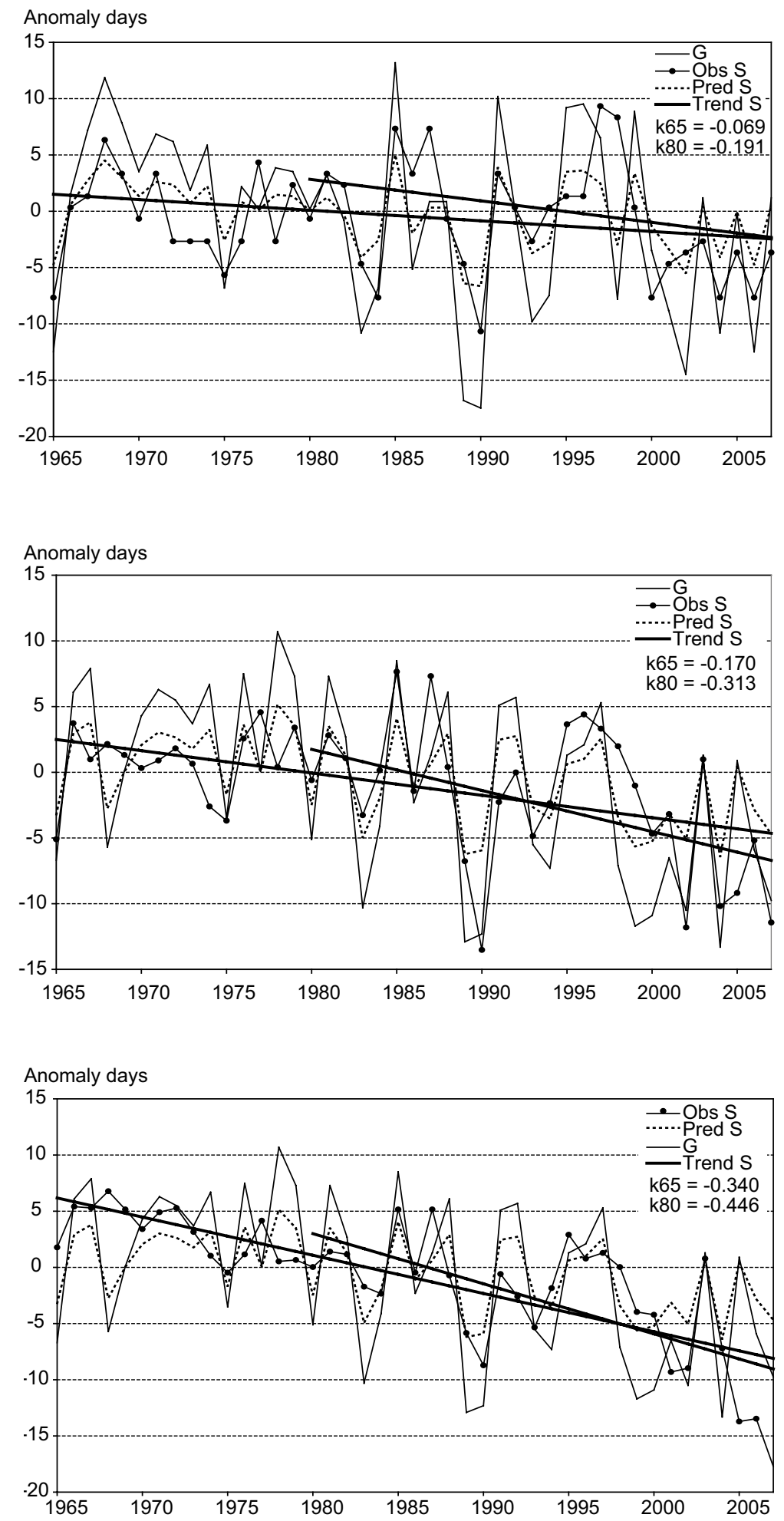
Vol. 17 (2008): 165-176.

crops the year effect was also significant (Table 4). The regression analysis with the detrended data (Table 5) and the graphical presentation of S and $\mathrm{G}$ in Figs. 2-6 confirm that the link between $\mathrm{S}$ and $\mathrm{G}$ existed at an annual level and was not merely a consequence of a common direction of the trends of $\mathrm{S}$ and $\mathrm{G}$.
Predicted S of spring cereals and sugar beet showed similar overall shifts over years and variation in the same direction from the trend lines as the observed S (Figs. 2-4, 6), though the earliest and latest sowings were not always fully predicted as expected. $\mathrm{S}$ and predicted $\mathrm{S}$ of potato varied similarly over years but the advance of predicted

Table 3. Trend of start of sowing (S) for spring cereals, potato and sugar beet in the regions east, north and west of Finland in 1965-2007: standardized Mann-Kendall statistics (MK), probability that MK< computed MK (pMK). Pearson correlation between $S$ and anomaly of growing season start relative to mean of 1971-2000 (G), for potato and sugar beet adjusted for year: correlation coefficient (R), significance of correlation (pR). Results from analysis using two types of smoothed daily temperature data are presented: (a) central moving average of 31 days, (b) daily values computed from monthly mean temperatures.

\begin{tabular}{lcccccccc}
\hline & $\mathrm{MK}$ & $\mathrm{pMK}$ & $\mathrm{R}$ & $\mathrm{pR}$ & $\mathrm{MK}$ & $\mathrm{pMK}$ & $\mathrm{R}$ & $\mathrm{pR}$ \\
\hline Spring cereals & (a) & & & & $(\mathrm{b})$ & & & \\
$\quad$ East & -1.508 & 0.132 & 0.742 & $<0.0001$ & -1.508 & 0.132 & 0.668 & $<0.0001$ \\
$\quad$ North & -1.389 & 0.165 & 0.635 & $<0.0001$ & -1.389 & 0.165 & 0.629 & $<0.0001$ \\
$\quad$ West & -2.669 & 0.008 & 0.677 & $<0.0001$ & -2.669 & 0.008 & 0.776 & $<0.0001$ \\
$\begin{array}{l}\text { Potato } \\
\quad \text { West }\end{array}$ & -5.644 & $<0.001$ & 0.404 & 0.008 & -5.644 & $<0.001$ & 0.742 & $<0.0001$ \\
$\begin{array}{l}\text { Sugar beet } \\
\quad \text { West }\end{array}$ & -3.120 & 0.002 & 0.468 & 0.002 & -3.120 & 0.002 & 0.674 & $<0.0001$ \\
\hline
\end{tabular}

Table 4. Regression model for the start of sowing (S) of spring cereals, potato and sugar beet in the regions east, north and west of Finland in 1965-2007. $\mathrm{R}^{2}$ is the coefficient of determination for each crop and region. Results from analysis using two types of smoothed daily temperature data are presented: (a) central moving average of 31 days, (b) daily values computed from monthly mean temperatures. Note different model structures. $\mathrm{G}=$ anomaly of growing season start relative to mean of $1971-2000$.

\begin{tabular}{clccc}
\hline & Param & Value & $\operatorname{Pr}>|\mathrm{t}|$ & $\mathrm{R}^{2}$ \\
\hline Spring cereals & Model $\mathrm{S}=\beta \mathrm{G}$ & & & \\
East & $\beta$ & 0.417 & $<0.0001$ & 0.56 \\
North & $\beta$ & 0.381 & $<0.0001$ & 0.41 \\
West & $\beta$ & 0.483 & $<0.0001$ & 0.47 \\
Potato (a) & Model S $=\alpha+\beta \mathrm{G}+\gamma$ Year & & & \\
West & $\alpha$ & 549 & $<0.0001$ & 0.64 \\
& $\beta$ & 0.240 & $<0.0001$ & \\
Potato (b) & $\gamma$ & -0.277 & $<0.0001$ & \\
West & Model S $=\alpha+\beta \mathrm{G}+\gamma$ Year & & & \\
& $\alpha$ & 441 & $<0.0001$ & 0.72 \\
Sugar beet & $\beta$ & 0.425 & $<0.0001$ & \\
West & $\gamma$ & -0.223 & $<0.0001$ & \\
& Model S $=\alpha+\beta \mathrm{G}+\gamma$ Year & & & \\
& $\alpha$ & 295 & 0.027 & 0.43 \\
\hline
\end{tabular}


Kaukoranta, T. and Hakala, K. Time of sowing affected by spring warming

Table 5. Regression model using data on spring cereals, potato and sugar beet in the regions east, north and west of Finland in 1965-2007, detrended by first-differencing. $\mathrm{R}^{2}$ is the coefficient of determination for each crop and region. Model is dS $=\beta \mathrm{dG}$, where $\mathrm{dS}$ and $\mathrm{dG}$ are once differenced start of sowing $(\mathrm{S})$ and anomaly of growing season start relative to mean of 1971-2000 (G). Results from analysis using two types of smoothed daily temperature data are presented: (a) central moving average of 31 days, (b) daily values computed from monthly mean temperatures. Note different model structures.

\begin{tabular}{lllllllll}
\hline & Param & Value & $\operatorname{Pr}>|\mathrm{t}|$ & $\mathrm{R}^{2}$ & Param & Value & $\operatorname{Pr}>|\mathrm{t}|$ & $\mathrm{R}^{2}$ \\
\hline Spring cereals & $(\mathrm{a})$ & & & & & (b) & & \\
$\quad$ East & $\beta$ & 0.409 & $<0.0001$ & 0.56 & $\beta$ & 0.439 & $<0.0001$ & 0.45 \\
$\quad$ North & $\beta$ & 0.302 & $<0.0001$ & 0.33 & $\beta$ & 0.471 & $<0.0001$ & 0.39 \\
$\quad$ West & $\beta$ & 0.378 & $<0.0001$ & 0.39 & $\beta$ & 0.625 & $<0.0001$ & 0.59 \\
$\begin{array}{l}\text { Potato } \\
\quad \text { West }\end{array}$ & $\beta$ & 0.194 & 0.0028 & 0.20 & $\beta$ & 0.411 & $<0.0001$ & 0.49 \\
$\begin{array}{l}\text { Sugar beet } \\
\quad \text { West }\end{array}$ & $\beta$ & 0.332 & 0.0002 & 0.28 & $\beta$ & 0.569 & $<0.0001$ & 0.45 \\
\hline
\end{tabular}

Fig. 6. Sugar beet in region west in Finland. Anomaly of growing season start relative to mean of 1971-2000(G) and anomaly of start of sowing: observed (Obs S), predicted $($ Pred $\mathrm{S}=295+0.384 \times \mathrm{G}-$ $0.149 \times$ Year), and linear trend during 1965-2007 and 1980-2007 (Trend S). Slope of trend since $1965(\mathrm{k} 65)$, since $1980(\mathrm{k} 80)$.

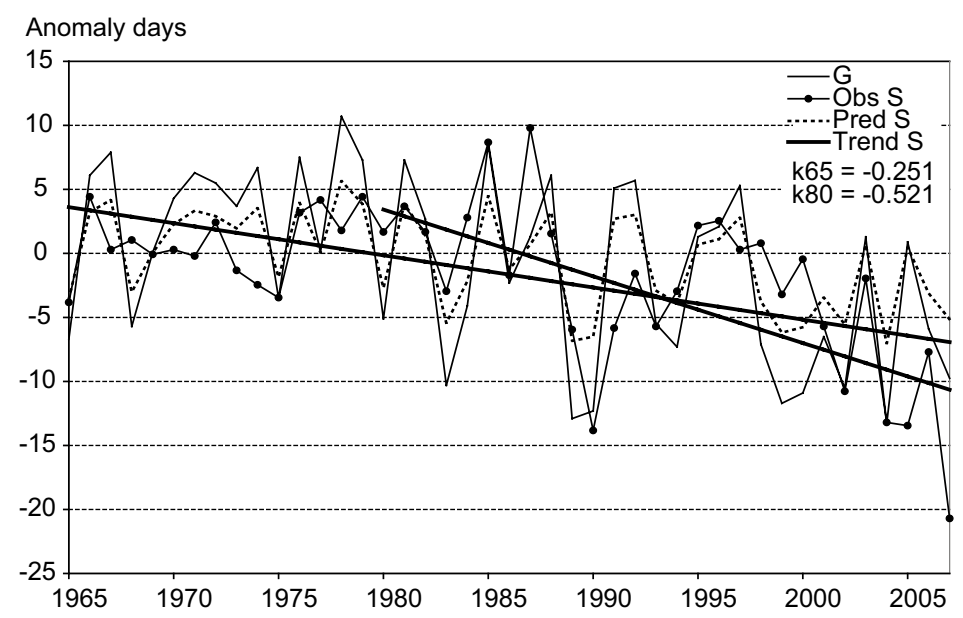

$\mathrm{S}$ was much less than the advance of observed $\mathrm{S}$ (Fig. 5).

Since the late 1970s, there has been an upward shift in spring temperatures. This was described by subjectively setting the start of trends at the year 1980. Using data smoothed with moving average, statistically significant $(p<0.01)$ linear trends since 1980 showed advances in G of 2.66, 2.18 and 2.92 days per decade in the east, north and west, respectively. Since 1980 S of spring cereals advanced over the full observation period 0.98 , 1.91 and 3.13 days per decade in the east, north and west (Figs. 2-6). Still the trend was statistically significant only in the west $(p<0.05)$. Pearson correlations between $\mathrm{G}$ and $\mathrm{S}$ were $0.86,0.68$ and 0.74 $(p<0.01)$. In the west, $\mathrm{S}$ of potato advanced 4.46 $(p<0.01)$ (Fig. 5) and S of sugar beet 5.21 days per decade $(p<0.01)$ (Fig. 6). Correlations were 0.39 and 0.36 ; both statistically significant $(p<0.01)$.

Mean temperatures during the early vegetative phase of cereals, 10-30 days after S, are plotted against years in Fig. 7. The temperatures oscillated widely, but there were no statistically significant trends. Early starts to the growing season (Figs. 2-4) were associated mostly with lower than average temperatures 10-30 days after $\mathrm{S}$, except in one 
Vol. 17 (2008): 165-176.

Anomaly mean temp. $10-30$ days after sowing

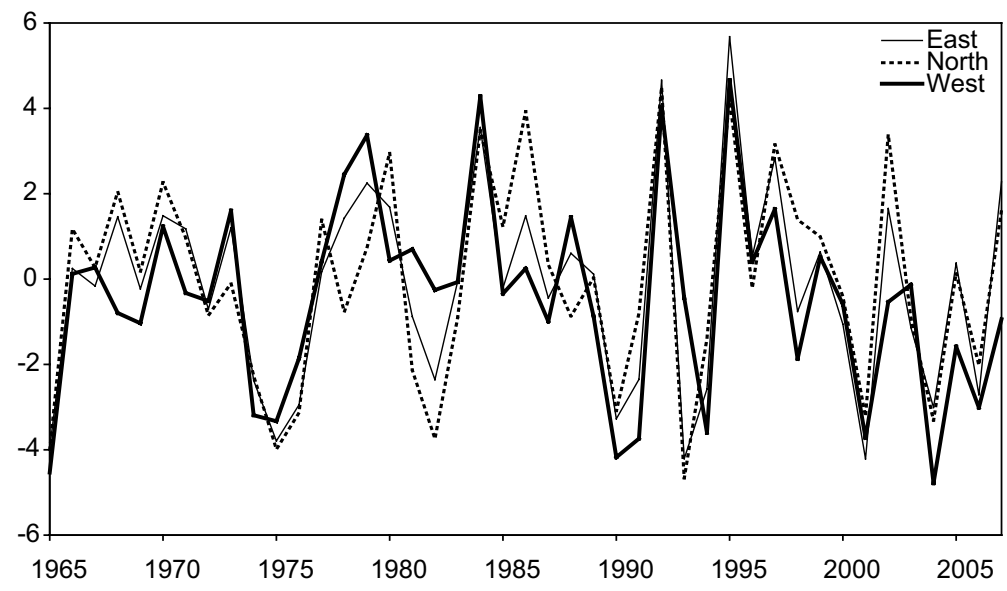

Fig. 7. Anomaly of mean temperature 10-30 days after start of sowing of spring cereals relative to mean of 1971-2000. year, 1984. Similar results were obtained for potato and sugar beet (results not shown).

\section{Discussion}

The time of sowing in the spring is governed by the interplay of soil characteristics, past weather conditions, conditions in the spring and the expected course of warming in the early summer. The decision to sow is made by the farmer, and it is based not only on these physical factors, but on other factors depending on the farmer as well. The interactions of the physical factors only are too complex to be interpreted statistically without simplification. Assuming that the spring temperatures and the expected course of warming are the key factors governing farmers' decision on sowing, and different crops are mostly grown on different soil types, the start of thermal growing season determined from smoothed daily temperature data intuitively explains sowing time well. The scarcity of light, sandy soils in Finland reduces the freedom of a farmer to freely choose when to sow spring cereals, such soils are generally being used for growing potato or sugar beet. The relative importance of soil characteristics as a factor affecting physical and actual sowing time is thus lessened. The smoothing of temperature data is needed to prevent a single cold or warm spell from arbitrarily shifting the start of the growing season by several weeks and to take into account forecasted and expected weather. In this study the smoothing was done either by computing 31 day moving averages or by interpolating from monthly mean temperatures. The latter method, which uses 61 days of information, provided better explanatory power in the west, especially for potato. It is likely that the longer smoothing period better represents soil temperature, which is more important for potato than for cereals and sugar beet.

According to the linear trends, the start of the growing season advanced 2.0-2.3 days per decade in the east and north over the years 1965-2007. Though early sowings match with early starts to the growing season, the trend for $\mathrm{S}$ of spring cereals did not differ significantly from zero during 1965-2007. Spring temperatures have shifted upwards since the late 1970s (Tuomenvirta 2004), which is seen as a steeper trend for the start of the growing season, since 1980 2.2-2.7 days per decade, and probably reflected by a steeper trend for S. However, the trend for S since 1980 is still not statistically significant for the regions east and north. In the west, the advance of growing season 


\section{AGRICULTURAL AND FOOD SCIENCE}

Kaukoranta, T. and Hakala, K. Time of sowing affected by spring warming

was larger than in the east and north, 2.6-2.8 days per decade during 1965-2007, since 19802.9 days per decade. In the west the advance of S was also larger and statistically significantly different from zero, 1.7 days per decade during the entire period, since 19803.1 days per decade. Sugar beet and potato sowing followed climatic change fully or even surpassed it. In the west, the $\mathrm{S}$ of sugar beet advanced 2.5 days and the potato planting 3.4 days per decade during the entire period. Since 1980 the rates have been 5.2 (sugar beet) and 4.5 days (potato) per decade. The rates of advance in the west during the full observation period were of similar magnitude as reported by Chmielewski et al. (2004) for crops in Germany and the expected rate for Finland before 2050 given by Carter (1998).

It cannot be exactly determined to what degree the recent warm springs in Finland are a consequence of long-term global climate change, yet if it is assumed that the warm springs reflect general climate warming, it seems likely that the observed advance of $\mathrm{S}$ in the western region of Finland is a consequence of global climate change. Regression analysis with the original and detrended data show that S responded annually to the start of the growing season, that is spring temperatures, and over the decades this has led to the earlier S.

Regression analysis suggests that $\mathrm{S}$ of sugar beet and potato was affected by factors other than climatic ones. Particularly in the case of potato, there are good reasons to assume this to be the case. From the 1960s, when potato was grown on all farms for local consumption, potato production has evolved into a highly specialized industry with increasingly intensive use of knowledge in the production and rapid responses to changes in demand by industry and consumers. As consumers have been willing to spend more money for fresh potatoes early in the season, some potato growers have responded by planting earlier despite higher costs incurred in the attempts to evade frost.

In addition, concentration of potato and sugar beet production on fewer farms, reduced area under grass crops, and increased farm size have led to higher workload per farm in the spring, which has intensified the need for early sowing over the time period under examination. In the northern semi-continental climate prompt sowing after the melting of soil frost and drying of the soil surface is needed to provide potential for good yield. Even though the increase in workload has been partly compensated for by more efficient machinery, it is probable that economic pressure for higher yields and better knowledge of farmers of the factors determining yield potential has pushed farmers to match the time of sowing ever more accurately with the weather conditions and soil moisture in the spring.

Menzel et al. (2006b) reported that in Germany farmers have not adjusted their sowing time in the spring as much as warming would have allowed. In Finland, partial response to warming might be a reasonable strategy to reduce frost risk at sensitive crop development stages. However, sowing cannot be delayed to such an extent that temperatures shortly after cereal seedling emergence would rise higher than they have during past decades. This would shorten the vegetative phase of spring cereals, increase early drought risk, or allow earlier arrival, relative to crop development, of migratory, temperature-dependent pests. By examining temperatures 10-30 days after sowing, it was found that the temperatures during the early vegetative phase of cereals have not increased. In fact, in almost all years when the growing season started early, temperatures 10-30 days after sowing were lower than the long-term average for all years during the same period. This indicates that to date the response of farmers to temperature change has been adequate.

Acknowledgements. This study was part of the project "Adaptation of Finnish agrifood sector to climate change", financed partially by the Ministry of agriculture and forestry of Finland. Prof. Timothy Carter is acknowledged for valuable scientific discussions and advice.

\section{References}

Carter, T.R. 1996. Developing scenarios of atmosphere, weather and climate for northern regions. Agricultural and Food Science in Finland 5: 235-249.

Carter, T.R. 1998. Changes in the thermal growing season in Nordic countries during the past century and pros- 


\section{AGRICULTURAL AND FOOD SCIENCE}

Vol. 17 (2008): 165-176.

pects for the future. Agricultural and Food Science in Finland 7: 161-179.

Chmielewski, F.M., Muller, A. and Bruns E. 2004. Climate changes and trends in phenology of fruit trees and field crops in Germany, 1961-2000. Agricultural and Forest Meteorology 121: 69-78.

Delbart, N. 2005. Télédétection de la phénologie dans les régions boréales. Diss. University of Toulouse III. $225 \mathrm{p}$.

Estrella, N., Sparks, T.H. \& Menzel, A. 2007. Trends and temperature response in the phenology of crops in Germany. Global Change Biology 13: 1737-1747.

Hu, Q., Weiss, A., Feng, S. \& Baenziger P.S. 2005. Earlier winter wheat heading dates and warmer spring in the US Great Plains. Agricultural and Forest Meteorology 135: 284-290.

IPCC 2001. Climate change 2001. The scientific basis. Contribution of Working Group I to the Third Assessment Report of the Intergovernmental Panel on Climate Change. (Eds.) Houghton, J.T., Ding, Y., Griggs, D.J., Noguer, M., van der Linden, P.J., Dai, X., Maskell, K. and Johnson, C.A. Cambridge University Press, Cambridge, UK, $881 \mathrm{p}$.

IPCC 2007. Summary for Policymakers. In: Climate Change 2007: The Physical Science Basis. Contribution of Working Group I to the Fourth Assessment Report of the Intergovernmental Panel on Climate Change. (Eds.) Solomon, S., Qin, D., Manning, M., Chen, Z., Marquis, M., Av- eryt, K.B., Tignor, M. and Miller, H.L. Cambridge University Press, Cambridge, UK and New York, NY, USA.

Jylhä, K., Tuomenvirta, H. \& Ruosteenoja, K. 2004. Climate change projections for Finland during the 21st century. Boreal Environment Research 9: 127-152.

Menzel, A. 2003. Plant phenological anomalies in Germany and their relation to air temperature and NAO. Climatic Change 57: 243-263.

Menzel, A., Sparks, T.H., Estrella, N., Koch, E., Aasa, A., Ahas, R., Alm-Kübler, K., Bissolli, P., Braslavská, O., Briede, A., Chmielewski, F. M., Crepinsek, Z., Curnel, Y., Dahl, A, Defila, C., Donnelly, A., Filella, Y., Jatczak, K., Måge, F., Mestre, A., Nordli, Ø., Peñuelas, J., Pirinen, P., Remišová, V., Scheifinger, H., Striz, M., Susnik, A., van Vliet, J.H., Wielgolaski, F.-E., Zach, S. \& Zust, A. 2006a. European phenological response to climate change matches the warming pattern. Global Change Biology 12: 1969-1976.

Menzel, A., von Vopelius, J., Estrella, N., Schleip, C. \& Dose, V. 2006b. Farmers' annual activities are not tracking speed of climate change. Climate Research 32: 201-207.

Schwartz, M.D. \& Reiter, B.E. 2000. Changes in North American spring. International Journal of Climatology 20: 929-932.

Tuomenvirta, H. 2004. Reliable estimation of climatic variations in Finland. Diss. University of Helsinki. 79 p. Finnish Meteorological Institute Contributions No. 43. 
Kaukoranta, T. and Hakala, K. Time of sowing affected by spring warming

\title{
SELOSTUS
}

\section{Keväiden lämpenemisen vaikutus kevätviljojen, perunan ja sokerijuurikkaan kylvöaikaan Suomessa}

\author{
Timo Kaukoranta ja Kaija Hakala \\ MTT Kasvintuotannon tutkimus
}

Tutkimuksessa arvioitiin historialliseen aineistoon perustuen, ovatko kevätviljojen, perunan ja sokerijuurikkaan kylvöajat aikaistuneet lämpimien keväiden seurauksena kolmella alueella Suomessa (itä, pohjoinen, länsi) vuosina 1965-2007. Alueille laskettiin vuosille 1965-2007 poikkeamat maatalouskeskusten havaintojen mukaisesta keskimääräisestä (1971-2000) kylvöjen alkamisesta. Samoille ajanjaksoille laskettiin poikkemat kasvukauden alkamisessa lämpötilan 31 vuorokauden liukuvan keskiarvon tai kuukauden keskilämpötiloista interpoloitujen vuorokauden keskilämpötilojen mukaan. Tilastollisesti merkitsevän lineaarisen trendin mukaan kasvukauden alkaminen on aikaistunut idässä ja pohjoisessa 2.0-2.3 päivää vuosikymmenessä, lännessä 2.6-2.8 päivää. Vuoden 1980 jälkeen trendin mukainen aikaistuminen on ollut idässä 2.7, pohjoisessa 2.2 ja lännessä 2.9 päivää vuosikymmenessä. Lineaarisen trendin mukaan kevätviljojen kylvön alku on aikaistunut idässä 0.6 (1980 jälkeen 1.0), pohjoisessa 0.7 (1980 jälkeen 1.9), ja lännessä 1.7 (1980 jälkeen 3.1) päivää vuosikymmenessä. Lännessä sokerijuurikkaan kylvö on aikaistunut 2.5 (1980 jälkeen 5.2), päivää ja perunan 3.4 (1980 jälkeen 4.5), päivää vuosikymmenessä. Ainoastaan lännessä kylvöjen aikaistuminen on tilastollisesti merkitsevää. Jos keväiden lämpeneminen olisi johtanut lämpimämpään säähän kevätviljojen orastumisen jälkeen, se olisi osittain poistanut aikaisemman kylvön hyödyn. Näin ei kuitenkaan ole tapahtunut, sillä lineaarisen trendin mukaan keskilämpötila 10-30 päivää kylvöjen alkamisesta ei ole noussut ja vuosina, jolloin kasvukausi on alkanut aikaisin, orastumisen jälkeinen vaihe on itse asiassa ollut keskimääräistä viileämpi. Ilmastollisten muutosten ohella kylvöjen alkamisaikaan on mahdollisesti vaikuttanut tilakohtaisen kylvöalan kasvu ja taloudellinen paine sadon maksimointiin. Perunan istutusta on epäilemättä aikaistanut myös varhaisperunan lisääntynyt käyttö. 